\title{
ENVIRONMENTAL PERCEPTION BY THE VISITORS OF URBAN PARKS IN THE CITY OF MARINGÁ, SOUTHERN REGION OF BRAZIL
}

\author{
PERCEPÇÃO AMBIENTAL DOS FREQUENTADORES DE PARQUES URBANOS \\ NA CIDADE DE MARINGÁ, REGIÃO SUL DO BRASIL
}

\author{
Silvio Alexandre Santos \\ Felipe Rafael Oliveira \\ Ana Paula Machado Velho \\ Luiz Felipe Machado Velho
}

\begin{abstract}
Urban parks are essential in improving the quality of life of the population in the cities. In this study, we sought to understand the perception of citizens about the importance of urban parks in the city of Maringá-PR, and the environmental aspects that involve their relationship with green areas. The parks analyzed were Parque do Ingá and Parque Municipal Alfredo Werner Nyffeler, both of which are widely frequented by the population. Exploratory field research was used, through the application of questionnaires, which covered questions related to the user's profile, environmental perception and the structure of the parks. 212 people were interviewed, 106 in each park. The feeling of well-being, as well as the benefits related to physical and mental health, and contact with nature, were the most highly valued attributes. It can be seen that these green areas make the urban environment more pleasant and play a fundamental role in improving the quality of life of the researched public. The subjective perception developed by visitors to green areas in urban centers shows the importance of developing public policies aimed at the implementation, conservation and management of urban parks, with a consequent expansion and improvement of urban sustainability.
\end{abstract}

Keywords: Green areas. Green spaces. Leisure areas. Human well-being. Quality of urban life. Urban Planning.

\section{Resumo}

Parques urbanos são essenciais na melhoria da qualidade de vida da população das cidades. Neste estudo, buscou-se compreender a percepção dos cidadãos sobre a importância de parques urbanos na cidade de Maringá$\mathrm{PR}$, e os aspectos ambientais que envolvem a relação dos mesmos com as áreas verdes. Os parques analisados foram o Parque do Ingá e o Parque Municipal Alfredo Werner Nyffeler, ambos amplamente frequentados pela população. Foi empregada pesquisa de campo exploratória, por meio de aplicação de questionários, que abrangiam questões referentes ao perfil do usuário, percepção ambiental e sobre a estrutura dos parques. Foram entrevistadas 212 pessoas, sendo 106 em cada parque. O sentimento de bem-estar, assim como os benefícios relacionados à saúde física e mental e o contato com a natureza foram os atributos mais altamente valorizados. Pode-se constatar que essas áreas verdes tornam o ambiente urbano mais agradável e exercem um papel fundamental na melhoria da qualidade de vida do público pesquisado. A percepção subjetiva desenvolvida nos visitantes de áreas verdes em centros urbanos evidencia a importância do desenvolvimento de políticas públicas direcionadas à implantação, conservação e gestão de parques urbanos, com aspectos fundamentais para a melhoria da sustentabilidade urbana.

Palavras-chave: Áreas verdes. Espaços verdes. Áreas de lazer. Bem-estar humano. Qualidade de vida urbana. Planejamento urbano. 


\section{INTRODUCTION}

To meet its basic survival needs, humanity has increasingly explored the resources made available by the environment without even thinking about the consequences of its actions, which in addition to ecological problems, also generate socio-cultural and economic problems (VITOUSEK et al., 1997; OPPLIGER et al., 2019). The environmental changes intensified after the implementation of the capitalist system, mainly after the Industrial Revolution, which caused a continuous and accelerated devastation to the environment, putting at risk the balance of ecosystems and the life of all humanity (SOUSA; HAYASHI, 2013).

The UN study World Population Prospects highlights that from 2019 , it is estimated that the world population will increase by approximately 30\% (just over two billion inhabitants) by 2050 . This growth is expected to occur mainly in urban centers, which most often lack efficient urban planning, which suffer from several problems related to increased pollution and suppression of native vegetation, and with increased pressure on green spaces (SILVA; VARGAS, 2010; JAMES et al., 2009). Thus, as cities grow, the need to create or maintain parks with green areas increases (MUÑOZ; FREITAS, 2017), fundamental elements for a greater environmental balance in cities and for the quality of life of the urban populations (COSTA; COLESANTI, 2011). To contain or alleviate urban problems caused by the intense industrialization process in the late nineteenth century, Ebenezer Howard (1898) proposed the construction of garden cities, maintaining a balance between urban growth and natural and rural aspects. Later, these ideas were adapted in the planning of cities in England, being carried out in the city of Letchworth, through the architects Raymond Unwin and Barry Parker, who defined in their project a city with winding streets, private gardens and parks, demonstrating the concern with the continuity of the open space (MENEGUETTI, 2007).

In the twentieth century, discussions about the importance of parks in cities have intensified, as these living spaces became increasingly necessary for the population (BOVO, 2009). Studies such as that by Konijnendijk et al. (2013) indicate that the presence of green areas in the urban space plays a strategic role for cities, with important functions for sustainable development. Thus, given the current demand for urban development and growth, it has become essential to investigate the importance of urban parks (KOTHENCZ; BLASCHKE, 2017; SANG et al., 2016), and the relevance of ecosystem services provided by these spaces to the quality of life and human well-being (BERTRAM; REHDANZ, 2015a; HAASE et al., 2014; KOTHENCZ; BLASCHKE, 2017; VAN DEN BERG; JORGENSEN; WILSON, 2014)few have focused on studies that assess urban ecosystem services (UES. However, environmental perceptions, as well as the relationship between the cultural ecosystem services, involving recreational, educational, aesthetic, spiritual and human welfare benefits, are not yet fully addressed (SANDIFER; SUTTON-GRIER; WARD, 2015). According to Costa and Colesanti (2011), studies based on the perceptual approach seek to understand how human beings respond to the physical environment around them, in other words, the individual's perception of his/her environment and the value he/she places on it. The environmental perception, in addition to being considered an important indicator of environmental quality, can help to better understand are the expectations of the population in relation to the green area they frequent, as well as contribute to the decisions that must be taken to improve this relationship (COSTA; COLESANTI, 2011).

The presence of urban green areas increases the aesthetic quality of a community and can reinforce the affective feelings of the community with its place. In addition to increasing self-esteem and the relationship of people with their neighborhood/municipality, these green areas act directly on public health, as they guarantee a healthier environment, with good air quality and provide adequate leisure environments for citizens to exercise (MENEGUETTI; REGO; BELOTO, 2009). Agenda 21 (BRAZIL, 2000) and the Sustainable Cities Document (BEZERRA; FERNANDES, 2000) emphasized the importance of urban parks to achieve sustainability goals. Among these goals, we highlight the improvement of the environmental quality of cities, through preventive actions, elaboration of urban plans and projects related to public green areas and the conservation of urban environmental her- 
itage, both built and natural and landscape. Therefore, urban parks make up an ideal environment to propose actions linked to the development of environmental perception and education, which can assist in changing attitudes and developing awareness of the environment (MELAZO, 2005).

Conceived along the lines of the garden-city concept, the city of Maringá, located in the southern region of Brazil, produced since its formation (1949), an ecological imaginary of a pleasant Green City with available services, which was strongly disseminated to attract new residents to the city, located in the state of Paraná (BOVO, 2009; GOLÇALVES, 1999). The exuberant Atlantic Forest existing at the time, now restricted to some urban parks in Maringá, is related to the beginning of the colonization process of the city, mainly by rural producers from São Paulo and Minas Gerais, attracted by the noble woods and by the rich and productive land (MENEGUETI, 2017). The contemporary occupation of these lands, driven mainly by economic development, triggered severe deforestation of the forest (LUZ, 1980). Cleaning the land was essential, and it should be quick, so that the colonizers could enjoy the land that was covered (LUZ, 1980; GONÇALVES 1999). Subsequently, in the early 1940s, the Companhia Melhoramentos Norte do Paraná (CMNP), largely responsible for the colonization of northern Paraná, delegated to engineer Jorge de Macedo Vieira the elaboration of the city project. Following the reasoning of the design of the first garden city, Vieira outlined the design of the city of Maringá with strong influence from structural aspects practiced in the English city of Letchworth (MENEGUETTI, 2007).

The ecological idealization of a green city resurfaced in the $1980 \mathrm{~s}$ in Maringá, thanks to the municipal government that, in addition to including in its government program projects related to landscaping and urbanism, carried out blunt and dominant advertising campaigns of a city planned without problems common in large urban centers (BOVO, 2009). However, it was only in the 1990s that Maringá made a leap in quality in environmental policy, with the drafting of numerous laws, decrees and proposals, linked to Eco-92 - Earth Summit - United Nations Conference on
Environment and Development, held in Rio de Janeiro, which attributed to municipalities the responsibility for preserving the local environment. Even so, the use and occupation of the municipality's urban space were more systematically influenced by the advertising discourses of the green ideal than by planned, disseminated and effective environmental practices (MOSTAGI; MANSANO, 2016). The dissemination of the green ideal in Maringá was carried out in a strategically operational way, both to reach the city's population and increase its visibility in the state of Paraná and in the country. Over the decades, it has been readjusted, expanded and sophisticated, always thinking about the construction of the green idealization to be recognized and assumed by the population (MOSTAGI; MANSANO, 2016).

Given this scenario, we seek, through this study, to understand the perception of citizens who frequent urban parks in Maringá-PR, regarding the environmental aspects that involve their relationship with these green areas. For this, an exploratory sample survey was carried out, through the application of a questionnaire and by direct approach to the visitors of two urban parks in the city. The questionnaire consisted of three topics, which covered issues related to i) the user's profile, ii) environmental perception provided by the parks and, iii) the structure offered by these urban spaces.

\section{Material and methods}

\subsection{STUDY AREA}

The study was developed in two urban parks located in the municipality of Maringá, Paraná, Brazil: Parque do Ingá and Parque Municipal Alfredo Werner Nyffeler (Figure 01).

The city of Maringá is the third largest city in the State of Paraná and the seventh in the southern region of the country, has an estimated population of 423,666 inhabitants, the majority (about $98 \%$ ) residing in the urban area. It has a Population Growth Index (Portuguese acronym: ICP) estimated at $1.86 \%$ and a Human 


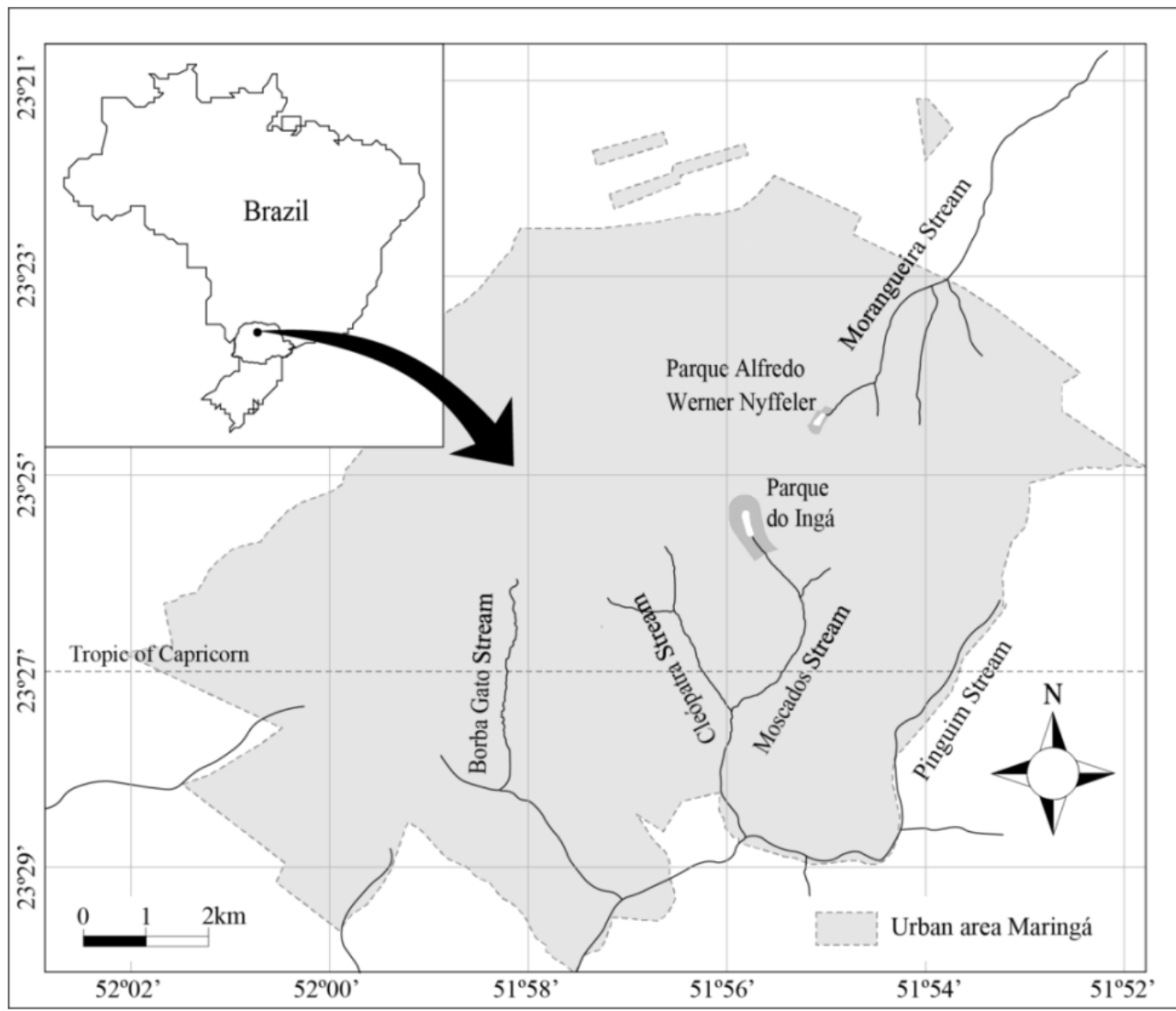

Figure 01 - Location of the Parque do Ingá and Parque Alfredo Werner Nyffeler in the urban perimeter of the city of Maringá - PR, Brazil.

Source: The authors, 2020.

Development Index (HDI) of 0.808 , occupying the $23^{\text {rd }}$ position in the country (IBGE, 2010).

Maringá is considered a planned city with very high environmental quality (SOUSA; HAYASHI, 2013). It is inserted in the Atlantic Forest biome; however, its original flora has suffered, and still suffers several environmental impacts due to urbanization, rural exodus and the policy of governments to "colonize" the interior of the country in an unsustainable way. Few areas of the Atlantic Forest included in the urban landscape have been preserved, including Parque do Ingá and the Parque Nyffeler (BORSATO; MARTONI, 2004), which are visited by a significant number of people, especially on weekends and, therefore, we consider these two parks as objects of our study.

\subsubsection{Parque do INGÁ}

The Parque do Ingá is located in the central area of Maringá, between the geographical coordinates $23^{\circ} 25^{\prime} \mathrm{S}$, and $51^{\circ} 55^{\prime} \mathrm{W}$, with 
an altitude of 557 meters and an area of $474,300 \mathrm{~m}^{2}$ (Figure 01). It established in 1971, by means of Municipal Law No. 880, and received this name due to the large number of trees of "ingá" (Inga marginata) existing in the park (BOVO, 2009). It became a permanent preservation area years later, with the Organic Law of the Municipality published in 04/17/1990. It is considered one of the most important and recreational green areas in the northwestern region of Paraná State, being visited constantly by tourists who pass through the city (BOVO; AMORIM, 2011). The park has trails and ecological pathways, where tourists can contemplate the natural aspects of flora and fauna. In addition, it has several tourist attractions aimed at contemplating the landscape and leisure, in natural environments (NIGRO; ANGELIS, 2016). In the surroundings of the reserve, structures dedicated to the practice of physical exercises are available to visitors, including outdoor gym and running/walking tracks.

According to the Management Plan (MARINGÁ, 2007), prepared by the City Hall and the State University of Maringá (UEM), the park has a lush vegetation, reminiscent of seasonal semi-deciduous forest, with predominance of native species. However, in the vicinity of the trails that make up the park, it is possible to notice the presence of several exotic species. This green area consists of large trees, typical of the climax stage, which alternate with other species typical of secondary succession stages, mainly due to the opening of clearings, caused by the fall of large trees (BOVO; AMORIM, 2011).

\subsubsection{Parque Municipal Alfredo WERNER NYFFELER}

The Parque Municipal Alfredo Werner Nyffeler is located in a less central area of the city, with more suburban characteristics, between the geographical coordinates $23^{\circ} 24^{\prime} \mathrm{S}$, and $51^{\circ} 55^{\prime} \mathrm{W}$, with an altitude of 520 meters and an area of 104,967.82 $\mathrm{m}^{2}$.

Implemented in 1988 by Municipal Law No. 0162/88, the Park, also known as Parque Buracão, is the result of the recovery of a rough terrain, in an intensive process of degradation and erosion. At the time, it received a significant amount of solid construction waste from the entire city and furniture that was discarded by the population and deposited in this area where the Morangueiro stream is located (BOVO; AMORIM, 2011). After a large investment by the Municipality of Maringá, the area was revitalized (SOUSA; HAYASHI, 2013). The Parque Nyffeler has a good quality physical structure, with lighting, trash cans, children's playground, gym for the elderly, running track and physical exercise equipment. Most vegetation is composed of native species; however, exotic species are also commonly found in its extension. The vegetation consists of arboreal, shrub strata and, more predominantly, grasses, which cover about $80 \%$ of the area of the park (BOVO, 2009).

\subsection{Data Collection}

To quantify and define the physical and psychological functions felt by users, transmitted by the green areas of the parks, interviews were conducted through the application of a questionnaire composed of 19 questions.

The open-ended questions offered alternatives and response scales ordered at a hierarchical level (multi-item measurement), to facilitate their application. They covered issues related to I) user profile, II) perception of visitors in relation to green areas; and III) park structure (supplementary material ESM_1).

The interviews were conducted in October 2016, at the beginning of the spring season, on a sunny day (from 9 am to $1 \mathrm{pm}$ ). In each of the parks, 106 questionnaires were applied simultaneously (212 in total), randomly involving people who practiced some activity in the parks.

The questionnaire sought to quantify the profile of users; users who frequent the park on weekends; the importance attributed to the park; the frequency of visits; ease and mode of transport; the user's relationship with the park, with emphasis on its importance for improving the quality of life; and assess the quality of the services offered. 
For the development of this research, the qualitative and quantitative methods were integrated. Although the two approaches are different in nature and are not continuous, nor are they contradictory, the advantages of one method can outweigh the limitations of the other (MINAYO; SANCHES, 1993).

For Steckler et al. (1992), qualitative methods help to interpret and explain quantitative results, while quantitative results help to interpret predominantly qualitative findings. Both methods are used in parallel to validate the results of the study. Due to the difficulty of determining the sample size, it was decided to conduct an exploratory research, by sampling, based on a survey carried out in the Parque do Ingá, in an action called Environment \& Health, promoted by students of undergraduate courses in Social Communication and Master's students in Health Promotion and in Clean Technologies, from the Unicesumar University.

According to Carmo and Ferreira (2008), for convenience sampling, a group of individuals available at the time of collection is used. It is an exploratory study whose results, obviously, cannot be generalized to the population to which the convenience group belongs, but from which precious information can be obtained.

\section{Results}

\subsection{USER PROFILE}

In general, there was a balance in relation to the users' gender. In the Parque do Ingá, $56 \%$ of the interviewers were female and $44 \%$ male. While in the Parque Nyffeler, $60 \%$ were male and $40 \%$ female.

The most prevalent age group in both parks was 30 to 39 years old. In the Parque do Ingá, the second most representative age group was between 40 and 49 years old, and in the Parque Nyffeler, people between 20 and 29 years old. People under 20 had low percentage values in both parks $(6 \%$ in the Parque Ingá and $7 \%$ in the Parque Nyffeler), as well as people over 60 years old, represented by 7 and $8 \%$ in the Parque Ingá and in the Parque Nyffeler, respectively (Figure 2 - A).

Most of the interviewed visitors were from residents close to the parks analyzed (Figure 2). In the Parque do Ingá, $42 \%$ of the participants lived in the central area of the city, where the Park is located, followed by the North Zone of the city $(28 \%)$. In this same park, it was possible to observe a considerable percentage of residents from other regions of Maringá ( $30 \%$ of the total). In relation to the Parque Nyffeler, the vast majority of its visitors (78\%) belong to the North Zone, the region where the park is located, with a record of few visitors from other regions of the municipality (Figure 2 - B).

When observing the family income data, it was found that the majority of visitors to the Parque do Ingá (36\%) are in class C, while in the Parque Nyffeler, class D (35\%) had a higher percentage. Classes $A$ and $B$, presented values of 7 and $13 \%$, respectively, in the Parque do Ingá, values that are much higher than those observed in the Nyffeler, which presented for these income classes percentage values of only $1 \%$ each (Figure 2 - C).

Regarding the visitors' education level, in the Parque do Ingá, $40 \%$ of them had completed higher education, $3 \%$ had a postgraduate degree and $28 \%$ have completed high school. People with elementary education represented $6 \%$, the same percentage verified for people with incomplete elementary education $(6 \%)$. In the Parque Nyffeler, the majority of respondents, $39 \%$, responded that they had at least completed high school, $16 \%$ had elementary school and $15 \%$ did not complete this level of education. The percentage of people with higher education was much lower than the values registered at the Parque do Ingá, with $15 \%$ having completed higher education; $6 \%$ with incomplete graduation and only $1 \%$ with post-graduation (Figure 2-D).

As for the frequency of visits, in a general context, in both parks, visitation occurs, especially, on weekends (Ingá 34\% and Nyffeler $40 \%$ ). People who rarely visit the parks also showed considerable percentage values, $36 \%$ in the Parque do Ingá and 32\% in the Parque Nyffeler (Figure 3-A). 


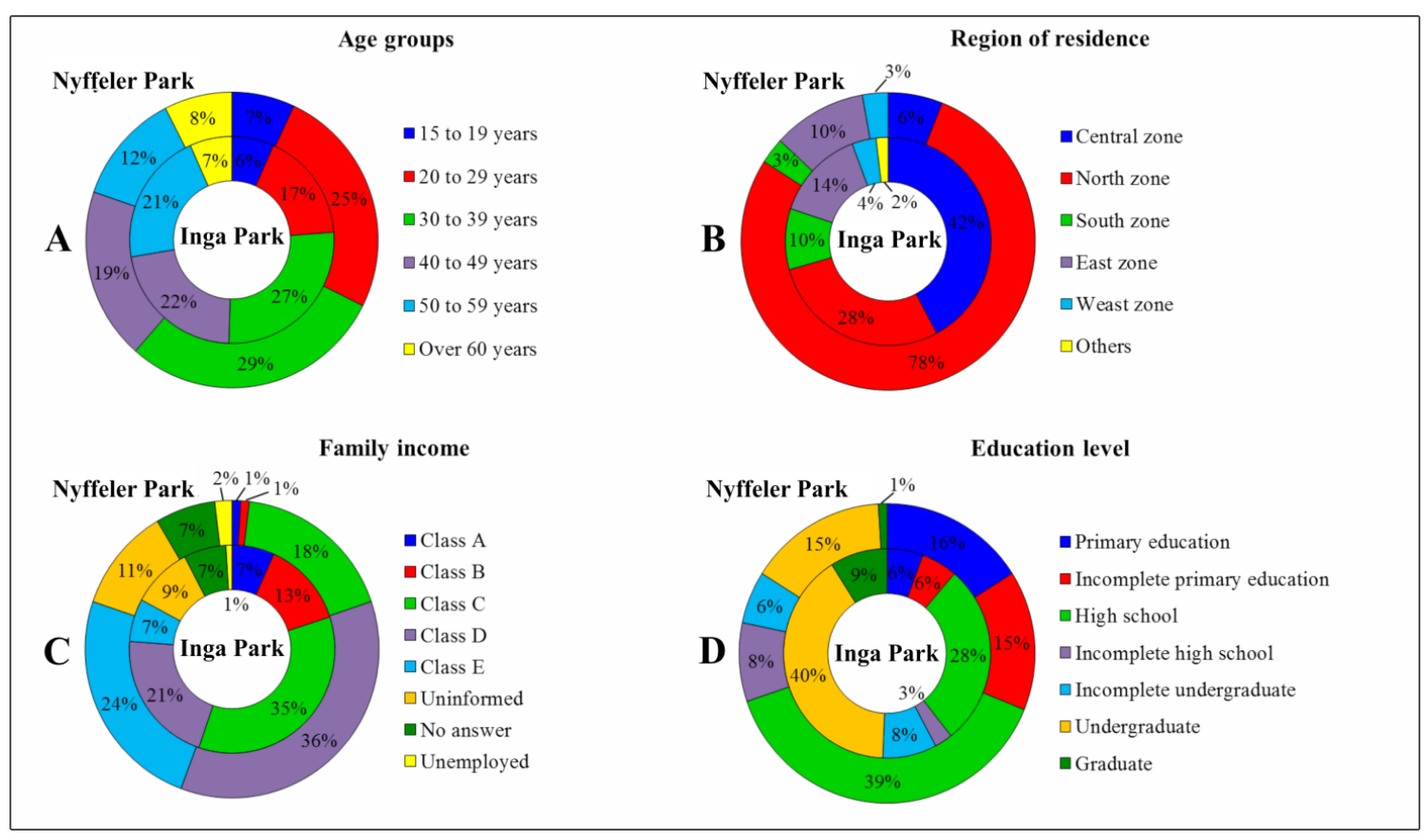

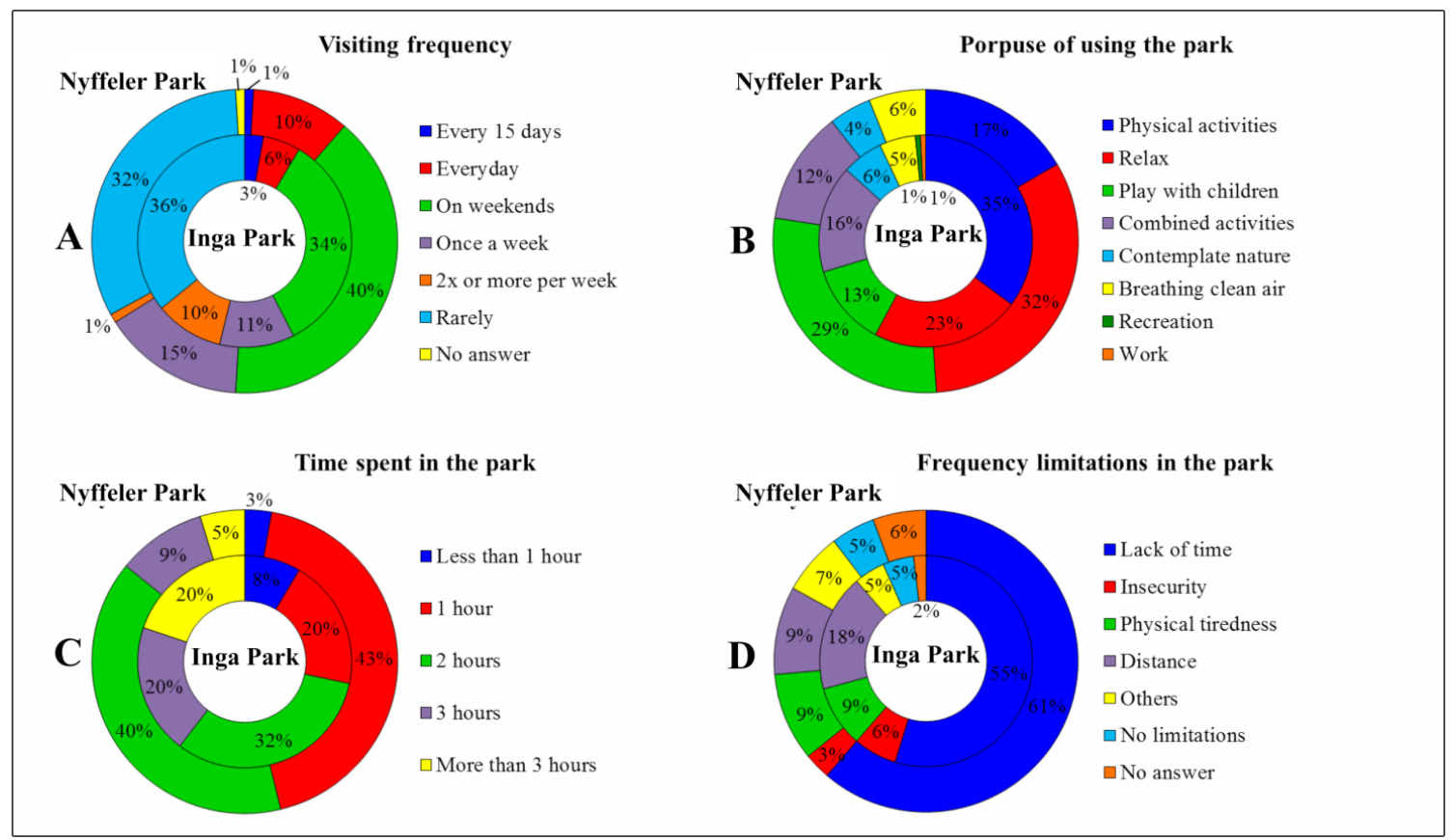

Figure 2 - Percentage values for gender, region of residence, socioeconomic profile and educational level of the public interviewed in the Parque do Ingá (inside) and in the Parque Nyffeler (outside) in the city of Maringá, PR.

Source: Authors, 2020

Figure 3 - Percentage values of frequency of visits, importance of the parks, time spent in the parks and limitations on visitation, according to the interviewees in the Parque do Ingá (inside) and in the Parque Nyffeler (outside), in the city of Maringá, PR.

Source: Authors, 2020 


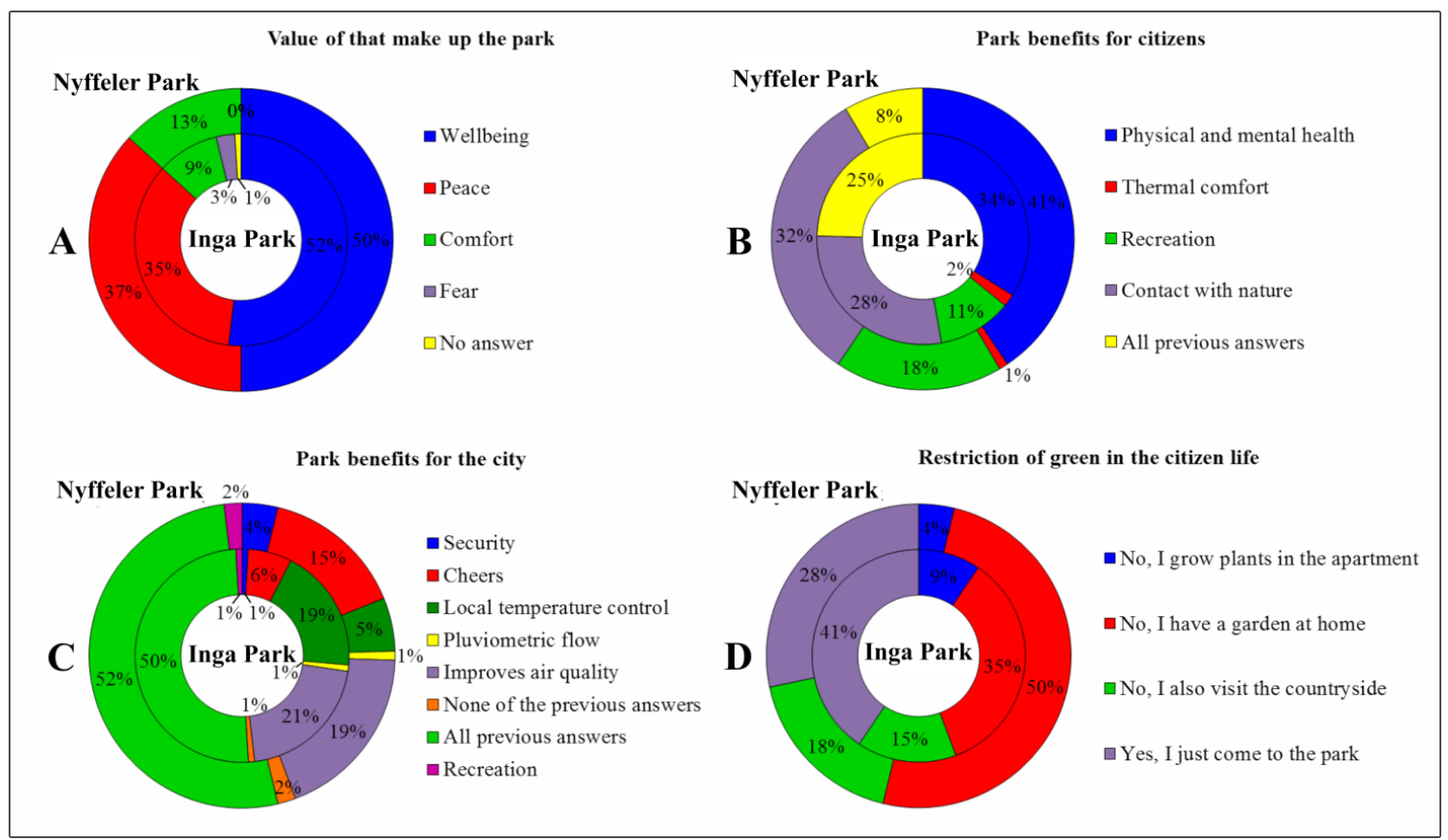

Figure 4 - Percentage values of the value of nature, importance of parks, benefits of parks for citizens and for the city, and restriction of green in the user's life, according to the interviewees in the Parque do Ingá de), in the city of Maringá, PR. Source: Authors, 2020

When asked about the purpose of using the Park (Figure 3-B), $35 \%$ of respondents in the Parque do Ingá stated that they resort to the area to develop physical activities; $23 \%$ to relax; $16 \%$ to practice of combined activities (which involves two or more activities); and $13 \%$ to play with their children. At the Parque Nyffeler, $32 \%$ of respondents seek the park to relax, $29 \%$ to play with their children, $17 \%$ to practice physical activities and $12 \%$ to combined activities. Still, in the Parque do Ingá, $32 \%$ of respondents said they would stay in the park for at least 2 hours. Those who stayed for 1 hour, for 3 hours and more than 3 hours were represented by $20 \%$ each. On the other hand, in the Parque Nyffeler, the vast majority of respondents, $43 \%$, said that they stayed in the park for 1 hour and another $40 \%$ for 2 hours (Figure $3-C)$.

As for the factors that limited the greater frequency of visitation of the population addressed, lack of time was the most cited impediment $(53 \%$, in the Parque do Ingá and $61 \%$ in the Nyffeler). However, distance $(9 \%$, in both parks) and tiredness $(18 \%$, in the Parque do Ingá and $9 \%$, in the Parque Nyffeler), were also often reported. In addition, for the Parque do Ingá, $5 \%$ of respondents said that there were no limitations that prevented them from visiting the park, the same value observed for the Parque Nyffeler (Figure 3-D).

\subsection{Environmental Perception}

The results reveal that the determining factor with the greatest positive effect, in all senses for all people interviewed, is the feeling of well-being. In the Parque do Ingá, $52 \%$ and in the Nyffeler $50 \%$ of respondents answered that this feeling was more expressive, followed by the feeling of peace, 35 and $37 \%$, respectively (Figure 4-A).

Regarding the benefits that parks provide for citizens, in the Parque do Ingá, 34\% emphasized that physical and mental health was the determining factor; $31 \%$, contact with nature; $11 \%$, leisure; and $2 \%$, thermal comfort. As for the Parque Nyffeler, $41 \%$ of the interviewed public also responded that physical and mental health was the main benefit; $32 \%$, contact with na- 
ture; $18 \%$, leisure; and only $1 \%$ highlighted thermal comfort as the most relevant benefit (Figure 4-B).

Users, when argued about the benefits that parks played for the city in general, responded that the ecological, social, aesthetic and outdoor leisure functions were the most important. Among respondents, in the Parque do Ingá, $21 \%$, improved air quality; $18 \%$, thermal comfort; $6 \%$, health; $50 \%$ consider all of these variables valid and the other $3 \%$ stated to have other reasons. Regarding the users interviewed in the Parque Nyffeler, $19 \%$ highlighted air quality; $15 \%$, health; $5 \%$, thermal comfort; $4 \%$, security; $52 \%$ considered all responses to be important, and $5 \%$ stated to have other reasons (Figure 4-C).

Analyzing data related to the restriction of access to green areas and the habit of cultivation of ornamental plants in their residences (Figure 4-D), a large portion of respondents in the Parque do Ingá said they had access to green areas only through the park $(41 \%)$, or that in addition to the park they also had a garden in their residence (35\%). As for those interviewed in the Parque Nyffeler, half of those interviewed (50\%) said they cultivate gardens at home and another $28 \%$ have access to green areas only through the park.

\subsection{PARK structure}

Regarding the quality assessment of the parks, in the Parque do Ingá, $49 \%$ considered the structure to be good, $27 \%$ considered it reasonable, $8 \%$ said it was very good and, $11 \%$, bad. As for the Parque Nyffeler, $56 \%$ considered it good; $25 \%$ considered it reasonable; $17 \%$ answered that it is very good and only $1 \%$ said it is bad (Table 1-A).

When analyzing the data on the use of the structure of the parks, it is observed that, in the Parque do Ingá, $25 \%$ of the interviewed use the trash cans, $23 \%$ use the drinking fountains or water points; $20 \%$ use the bathroom, $14 \%$ use the physical exercise equipment, $3 \%$ use the entire structure, $5 \%$ eat in the park and $6 \%$ answered that they do not use the structure that the park of-
Table 1: Percentage values referring to the structure and problems found in the Parque do Ingá and in the Parque Nyffeler, in Maringá, PR.

\begin{tabular}{|c|c|c|}
\hline \multicolumn{3}{|l|}{ A) Park Quality Evaluation } \\
\hline & $\begin{array}{l}\text { Parque } \\
\text { do Ingá }\end{array}$ & $\begin{array}{l}\text { Parque } \\
\text { Nyffeler }\end{array}$ \\
\hline Bad & $11 \%$ & $1 \%$ \\
\hline Reasonable & $27 \%$ & $25 \%$ \\
\hline Good & $49 \%$ & $56 \%$ \\
\hline Very Good & $8 \%$ & $17 \%$ \\
\hline Did not Answer & $5 \%$ & $1 \%$ \\
\hline \multicolumn{3}{|c|}{ B) What is Used in the Park's Structure } \\
\hline Bathrooms & $20 \%$ & $20 \%$ \\
\hline Trash Cans & $25 \%$ & $21 \%$ \\
\hline Water Fountains/Water Points & $23 \%$ & $26 \%$ \\
\hline Food service & $5 \%$ & $6 \%$ \\
\hline Exercise Equipment & $14 \%$ & $13 \%$ \\
\hline Other & $4 \%$ & $2 \%$ \\
\hline Nothing & $6 \%$ & $10 \%$ \\
\hline Everything & $3 \%$ & $1 \%$ \\
\hline \multicolumn{3}{|l|}{ C) Main Problems in the Park } \\
\hline Lack of Maintenance & $29 \%$ & $17 \%$ \\
\hline Trash & $12 \%$ & $12 \%$ \\
\hline Lack of Internal Security & $25 \%$ & $23 \%$ \\
\hline Odors & $3 \%$ & $2 \%$ \\
\hline Animals and Insects & $8 \%$ & $4 \%$ \\
\hline Other & $7 \%$ & $7 \%$ \\
\hline No Problems & $13 \%$ & $29 \%$ \\
\hline Did not Answer & $2 \%$ & $5 \%$ \\
\hline
\end{tabular}


fers. As for respondents at the Parque Nyffeler, $26 \%$ responded that they use drinking fountains and water points; $21 \%$, trash cans; $20 \%$, bathrooms; $13 \%$, exercise equipment; $10 \%$ do not use any of the facilities offered, $6 \%$ eat in the park and only $1 \%$ responded that they use the entire structure offered (Table 1-B).

Regarding the main problems existing in the parks, we observed that although a considerable portion of the interviewees $(13 \%)$ did not observe problems for the Parque do Ingá, $29 \%$ stated they were unhappy with the lack of maintenance, followed by the lack of security $(25 \%)$, the most cited problems. As for the respondents at the Parque Nyffeler, $29 \%$ observed no problems, $23 \%$ highlighted the lack of internal security and $17 \%$ were unhappy with the lack of maintenance in the park (Table 1-C).

\section{Discussion}

Urban parks have been intensely transformed throughout the recent history of Western society, and have always been seen as places where nature deserved to be conserved and revered (RAIMUNDO; SARTI, 2016). Natural environments as well as built environments are perceived according to the values and individual experiences of human beings, who attribute values and meanings to a certain degree of importance in their lives (MELAZO, 2005).

In this study, a moderate balance in relation to the gender of visitors in the urban parks studied was observed. However, in isolation, the survey results revealed a greater number of female audiences in the Parque do Ingá, and of male audiences in the Parque Nyffeler. The difference in the frequency of use of urban parks or green spaces by different genders has been discussed in some studies. For example, Cohen et al. (2007) and Schipperijn et al. (2010) observed that the frequency of visitation by women was lower than that of men in the parks analyzed, with men being twice as likely to be vigorously active in attending the parks (COHEN et al., 2007), especially as they get older (SCHIPPERIJN et al., 2010).
The predominant age group among the regulars visitors, in both parks analyzed, was largely composed of adults between 20 and 49 years old. This age group was also observed as predominant by Araujo and Barreto (2018), in an urban park in the city of Brasília, Brazil. The frequency of young people aged between 15 and 20 and elderly people over 60 was considered low, especially on weekends. Regarding age, it is likely that there are different restrictions that limit visits to urban green spaces, such as difficulty in urban mobility, displacement, accessibility, tiredness and physical limitations (RIECHERS; BARKMANN; TSCHARNTKE, 2016). Access to these spaces often varies between user groups and is connected to opportunity, motivation and ease of use (LACHOWYCZ; JONES, 2013).

In addition, it is known that restrictions on access to the use of green spaces and the infrastructure and landscape compositions that the parks offer can attract or repel different social groups (RIECHERS; BARKMANN; TSCHARNTKE, 2016). Thus, the cultural diversity of citizens must be recognized as a prerequisite for a socially just city project, considering that the effects and demands of age groups, as well as different cultural or social origins, become important points in the planning process of these environments (ERNSTSON; SÖRLIN; ELMQVIST, 2008; FAEHNLE et al., 2014; KABISCH; HAASE, 2014; RIECHERS; BARKMANN; TSCHARNTKE, 2016). This has broader implications, especially on where urban parks should be implemented and how accessibility to them will be maintained with all demographic groups in mind (ERNSTSON; SÖRLIN; ELMQVIST, 2008; KIM; RUPPRECHT; FURUYA, 2018). In a way, the parks analyzed in this study offer an equitable and comprehensive infrastructure, providing easy access to users, outdoor gyms, benches, drinking fountains, lighting, trash cans, children's playground, running track and exercise equipment. Therefore, other factors could explain a low percentage value of younger groups and of people over 60 years old, in the studied period.

The results found here follow the same pattern observed by Payne et al. (2002), in Ohio, in the United States. The authors 
showed that age was a strong indicator of behavior and preferences, with older people being less likely to visit parks. However, inverse results have been observed in Canada, by Kaczynski et al. (2009), who showed the existence of a stronger relationship between the levels of physical activity and living close to urban parks between young groups (18 and 34 years old) and older groups (over 55 years old). This result is probably related to the new concepts of quality of life and the need for direct contact with nature, which are becoming increasingly important (TOMIAZZI et al., 2006).

In this study, the results showed that the main reason for citizens to search and visit the parks is to relax, to play with children, to develop other combined activities, and to practice physical activities. This indicates that parks, besides leisure, are perceived as suitable places for the most diverse types of activities. In addition, these results reinforce the importance of these environments in areas of cities that are not necessarily central, considering that it is the residents close to these environments that seek these spaces, mainly, for the practice of physical activities and for walks (COHEN et al., 2007; KORAMAZ; TÜRKOĞLU, 2018). In this study, both parks studied seem to fulfill the role of providing environments suitable for physical activity practices to their visitors; however, in the Parque do Ingá, the search for the park for this purpose stood out.

The location and distance of the studied parks proved to be a strong condition of interference in the frequency of visits by the Maringá population. The results showed that the visits are mostly made by local residents, which was more evident for the Parque Nyffeler, where $72 \%$ of users live in the same neighborhood where the park is located. In fact, the greater proximity of a park in relation to the residences is among the main determinants for the adhesion and maintenance of the frequency of visitors (SZEREMETA; ZANNIN, 2013), and the distance ends up being one of the main reasons that prevent a greater frequency of visitors from making use of these environments (NICHOLLS; SHAFER, 2001; SZEREMETA; ZANNIN, 2013), especially the elderly (KIM; RUPPRECHT; FURUYA, 2018).
The urban green areas that are easily accessed are more used by the local community, especially for those who are unable to move long distances (GILES-CORTI et al., 2005). In a study carried out in urban parks in Curitiba, Brazil, Hildebrand et al. (2001) observed that there is an inversely proportional relationship between the distance to the parks and the frequency of users, according to the neighborhoods in which they live. In other words, the greater the distance from the parks to the citizens' house, the smaller the number of visitors from these neighborhoods. In another study, in Gothenburg, Sweden, Sang et al. (2016) identified that access to urban parks was a primary factor for the population to take advantage of the psychological and physiological benefits provided by them.

In addition, the location of the parks also proved to be an important factor, which influenced the results obtained in relation to the profile of the interviewed public, especially regarding the level of education and socioeconomic profile. In the Parque do Ingá, when compared to the Parque Nyffeler, a greater number of people with higher education and higher family income were observed. The location of this park in the central and prime area of the city, close to universities and surrounded by malls, stores and commerce in general, may explain these higher values. It is worth mentioning that the Parque do Ingá is known as an important symbol of the city, which is widely publicized by the media and, therefore, receives great visitation from people from other regions of the city and from several municipalities (BOVO; AMORIM, 2011; SOUSA; HAYASHI, 2013).

Parks located a short distance from the residence, when well planned, provide basic recreational needs and contribute to the local quality of life of their users as they satisfy and contribute to meeting the needs of the residents of the neighborhood (TYRVÄINEN; MÄKINEN; SCHIPPERIJN, 2007). On the other hand, the frequency of use of more central parks in the city, such as the Parque do Ingá, contributes to quality of life in a more general context, because, in addition to satisfying the local population, it provides leisure activities and tourism for people from more distant neighborhoods and other cities (KORAMAZ; TÜRKOĞLU, 
2018). This result is corroborated by the study by Takahashi and Martins (1990), who analyzed the place of residence of visitors to the Parque do Ingá and found that $52.2 \%$ of visitors were distributed among the most distant neighborhoods and $26.3 \%$ came from other cities, which reinforces the importance of this park to the city, with regard to leisure, recreation and tourism. Another interesting aspect to be considered is that, although the greater distance is a factor that determines a lower frequency of visits in urban parks, the lack of time is the factor that most restricts the visitation of the population in these environments. This argument represented, in both parks analyzed, more than $50 \%$ of the interviewed.

Regarding the benefits of green space for citizens and for the city, the values found in this research were equitable. Human perception is guided by the senses, being a fundamental factor for the assessment of the individual's relationship with the space where he/she lives and how he/she views the external world (FERREIRA, 2005). For citizens, when asked about the sentimental value that a park trigger in their lives, several feelings were mentioned, such as peace, comfort and even fear. However, the feeling of well-being was the most common. In fact, the feeling of well-being always presents expressive values in studies related to environmental perception, focusing on parks and urban green areas (BERTRAM; REHDANZ, 2015b; TZOULAS et al., 2007). For example, it has been shown that contact with nature in cities, triggers several positive impacts on human well-being, with repercussions on the health of the population (BERTRAM; REHDANZ, 2015b). Furthermore, according to Ferreira (2005), the feeling of well-being experienced by users also favors the achievement of other benefits, such as leisure, contact with nature and the promotion of physical and mental health. These benefits are seen as the main contributions of parks to the city, in a broader and more general context, confirming the appreciation of functions that are directly related to individual and family interests.

In addition to social, aesthetic and outdoor leisure functions, parks play important ecological functions and ecosystem services for the city (ANDRADE; ROMEIRO, 2009; MUÑOZ; FREITAS, 2017; RAIMUNDO; SARTI, 2016). Although users of urban parks classify ecosystem services as important elements of nature (JIM; CHEN, 2008), only a fraction of the services and benefits that the space provides is recognized directly by users (BUCHEL; FRANTZESKA$\mathrm{KI}, 2015)$. The user may, for example, experience a cooling and purity effect in the air, compared to the urban areas around the park, but the user will not directly perceive other services, such as carbon sequestration and storage that the trees in the parks perform (BUCHEL; FRANTZESKAKI, 2015; JIM; CHEN, 2008). In this study, the majority of respondents considered that parks contribute to improving urban air quality and people's health, and that the presence of these spaces helps to control the temperature of the environment, providing greater thermal comfort. In this way, even if the regular visitors do not perceive all the ecosystem services performed by the green in cities, these areas generate a positive effect and become a reference not only natural, but also cultural and subjective (FERREIRA, 2005), contributing to quality of life in cities. They also assume strategic importance to guarantee quality living conditions, both in central and peripheral areas (BONAIUTO; FORNARA; BONNES, 2003; CHIESURA, 2004; RAIMUNDO; SARTI, 2016).

Urban green spaces are, in most cases, the only direct contact of human beings with natural environments and, for this reason, many studies have focused attention on how these spaces improve the quality of life of residents and the urban environment (KIM; RUPPRECHT; FURUYA, 2018). People visit green spaces, often, in search of feelings that are not provided in the daily lives of cities. Among them are: relaxation, freedom, closeness and contact with nature. These are seen as essential and fundamental to provide, above all, personal well-being (CHIESURA, 2004).

The approach to nature also allows users to question their values and attitudes towards the environment through their perceptions, stimulating them to practice increasingly sustainable in their daily lives (DORIGO; FERREIRA, 2015). Thus, urban parks are an ideal environment to propose actions linked to the develop- 
ment of environmental perception and education, helping in the process of changing attitudes and developing awareness of the environment (MELAZO, 2005).

In general, all interviewees demonstrated, in their responses, the relevance of parks for citizens and the city, especially in terms of quality of life, through feelings such as well-being and relaxation. In addition, the search for physical and leisure activities in places considered green and free reaffirms the idea of parks as an element that contributes to the improvement of the quality of life of the population, becoming one of the main elements of public planning activities in establishing parks and green areas (KORAMAZ; TÜRKOĞLU, 2018; MASSAM, 2002). Important characteristics like these imply that improving availability and accessibility to urban parks and encouraging frequent use for leisure and tourism activities would be among the essential policies to increase the population's quality of life (KORAMAZ; TÜRKOĞLU, 2018).

With this, establishing and maintaining parks and green areas, connected to the idea of an urban forest, requires time, resources and patience, but it is something fundamental that decision makers and public policy makers need to consider, to offer more suitable places, to improve the quality of life of citizens and cities (RAIMUNDO; SARTI, 2016). Therefore, the understanding of environmental perception can be an important factor for the conservation or maintenance of green areas, as a way of guaranteeing communities a pleasant space for social interaction.

\section{Conclusion}

From this study, it was found that green areas in urban centers play a fundamental role in improving the quality of urban life. These spaces create a more pleasant urban environment, reinforcing social relations and making it possible to strengthen citizens' contact with nature and greater care and preservation of these spaces.
Enabling green and leisure areas in different locations in the same city, for example, in more distant neighborhoods, becomes an important issue to be debated by decision makers, and it is up to them, through appropriate public policies, to carry out an efficient and well-targeted planning for the construction, management and conservation of new urban parks. It was evident in this study that the vast majority of visitors to the parks analyzed were people who lived close to them, which reaffirm the idea that these parks fulfill their main role of improving the quality of life of the urban population. In addition, the structures, as well as the physical space that the parks offer, are positive elements that create a desire in people to visit these areas, even though some criticisms have been made regarding the conservation and maintenance of some structural items during the survey.

It is evident that more investments in green leisure areas should be considered, that sustainably accompanies the growth of cities and that they consider in their projects the democratization of these spaces, inclusion, accessibility, provision of adequate infrastructure and security for their visitors. Furthermore, public policies should allow for a closer and more active participation of the population in the involvement of planning and public policy issues. Because, clearly, to the extent that a social, sustainable and environmentally healthy space is offered for the leisure and sociability of the population, greater and better quality of life will be offered.

Regarding the limitations of the study, it was not possible to quantify the environmental perception of park users by gender, family income classes and age groups, due to the way the collected data was structured. This information could further enrich the results of this study. Therefore, it is suggested that new research be carried out in the near future that considers these aspects not addressed here. 


\section{Bibliographic References}

ANDRADE, Daniel Caixeta; ROMEIRO, Ademar Ribeiro. Serviços ecossistêmicos e sua importância para o sistema econômico e o bem-estar humano. Texto para Discussão, n. 155 , p. 44,2009

ARAUJO, Nayane Martins de; BARRETO, Cristiane Gomes. Parques urbanos: o caso do parque de uso multiplo da asa sul. Anais do IX Simpósio Nacional de Ciência e Meio Ambiente - SNCMA - III CIPEEX, v. 2, p. 582-592, 2018.

BERTRAM, Christine; REHDANZ, Katrin. Preferences for cultural urban ecosystem services: Comparing attitudes, perception, and use. Ecosystem Services, v. 12, p. 187-199, 2015. DOI: http://dx.doi.org/10.1016/j.ecoser.2014.12.011.

BERTRAM, Christine; REHDANZ, Katrin. The role of urban green space for human well-being. Ecological Economics, v. 120, n. 2015, p. 139-152, 2015. DOI: http://dx. doi.org/10.1016/j.ecolecon.2015.10.013.

BEZERRA, Maria do Carmo de Lima; FERNANDES, Marlene Allan. Cidades Sustentáveis - Subsídios à elaboração da Agenda 21 Brasileira. Brasília: Ministério do Meio Ambiente; Instituto Brasileiro do Meio Ambiente e dos Recursos Naturais Renováveis; Consórcio Parceria 21 IBAM-ISER-REDEH, 2000. Disponível em: http://www.sinduscondf.org.br/portal/arquivos/cidadessustentaveismma.pdf.

BONAIUTO, Marino; FORNARA, Ferdinando; BONNES, Mirilia. Indexes of perceived residential environment quality and neighbourhood attachment in urban environments: A confirmation study on the city of Rome. In: Landscape and Urban Planning, 2003 , v. 65 , p. 41-52. DOI: https://doi.org/10.1016/S0169-2046(02)00236-0.

BORSATO, Fabiano; MARTONI, Astrid Meira. Estudo da fisiografia das bacias hidrográficas urbanas no Município de Maringá, Estado do Paraná. Acta Scientiarum. Human and Social Sciences, v. 26, n. 2, p. 273-284, 2004. DOI: https://doi. org/10.4025/actascihumansoc.v26i2.1391

BOVO, Marcos Clair. Áreas verdes urbanas, imagem e uso: um estudo geográfico sobre a cidade de Maringá -PR. $324 \mathrm{f}$. Tese (doutorado) - Universidade Estadual Paulista, Faculdade Ciências e Tecnologia, 2009. Disponivel em: http://hdl.handle. net/11449/105006.

BOVO, Marcos Clair; AMORIM, Margarete Cristiane de Costa Trindade. Análise Diagnóstico dos parques urbanos em Maringá (PR) Brasil. Geo UERJ, v. 2, n. 22, p. 323-349, 2011

BRAZIL. Agenda 21 brasileira: bases para discussão. Brasília: [s.n.], 2000. Disponível em: https://www.mma.gov.br/responsabilidade-socioambiental/agenda-21/documentos. html.

BUCHEL, Sophie; FRANTZESKAKI, Niki. Citizens' voice: A case study about perceived ecosystem services by urban park users in Rotterdam, the Netherlands. Ecosystem ecosystem services by urban park users in Rotterdam, the Netherlands. Ecosystem

CARMO, Hermano; FERREIRA, Manuela Malheiro. Metodologia da investigação - Guia para Auto-aprendizagem. 2 ed. Lisboa: Universidade Aberta, 2008.
CHIESURA, Anna. The role of urban parks for the sustainable city. Landscape and Urban Planning, v. 68, n. 1, p. 129-138, 2004. DOI: https://doi.org/10.1016/j.landurbplan.2003.08.003

COHEN, Deborah A; MCKENZIE, Thomas L.; SEHGAL, Amber; et al. Contribution of public parks to physical activity. American Journal of Public Health, v. 97, n. 3, p. 509-514, 2007. DOI: https://doi.org/10.1016/j.landurbplan.2003.08.003

COSTA, Renata Geniany Silva; COLESANTI, Marlene Muno. A contribuição da percepção ambiental nos estudos das áreas verdes. RA' EGA - O Espaco Geografico em Analise, v. 22, n. 22, p. 238-251, 2011

DORIGO, Tania; FERREIRA, Ana Paula. Contribuições da Percepção Ambiental de Frequentadores Sobre Praças e Parques no Brasil (2009-2013): Revisão Bibliográfica. Revista de Gestão Ambiental e Sustentabilidade, v. 4, n. 3, p. 31-45, 2015. DOI: http://www.revistageas.org.br/ojs/index.php/geas/article/view/138

ERNSTSON, Henrik; SÖRLIN, Sverker; ELMQVIST, Thomas. Social movements and ecosystem services - The role of social network structure in protecting and managing urban green areas in Stockholm. Ecology and Society, v. 13, n. 2, 2008. DOI: https:// doi.org/10.1016/j.landurbplan.2003.08.003

FAEHNLE, Maija; BÄCKLUND, Pia; TYRVÄINEN, Liisa; et al. How can residents' experiences inform planning of urban green infrastructure? Case Finland. Landscape and Urban Planning, v. 130, n. 1, p. 171-183, 2014. DOI: http://dx.doi.org/10.1016/j. landurbplan.2014.07.012.

FERREIRA, Adjalme Dias. Efeitos Positivos Gerados Pelos Parques Urbanos: O caso do passeio Público da Cidade do Rio de Janeiro. Dissertação (Mestrado em Ciência Ambiental). Universidade Federal Fluminense, 2005.

GILES-CORTI, Billie; BROOMHALL, Melissa H; KNUIMAN, Matthew; et al. Increasing walking: How important is distance to, attractiveness, and size of public open space? In: American Journal of Preventive Medicine, 2005, v. 28, p. 169-176. DOI: https:// doi.org/10.1016/j.amepre.2004.10.018.

GOLÇALVES, José Henrique Rollo. Quando a imagem publicitária vira evidência factual: versões e reversões do Norte (Novo) do Paraná-1930/1970. In: DIAS, Reginaldo Benedito.

GOLÇALVES, José Henrique Rollo (Orgs.). Maringá e o Norte do Paraná: estudos de história regional. Maringá: EDUEM, 1999

HAASE, Dagmar; LARONDELLE, Neele; ANDERSSON, Erik; et al. A Quantitative Review of Urban Ecosystem Service Assessments: Concepts, Models, and Implementation. AMBIO, v. 43, n. 4, p. 413-433, 2014. DOI: http://link.springer.com/10.1007/s13280 014-0504-0.

HILDEBRAND, Elisabeth; GRAÇA, Lr; MILANO, Ms. Distância e deslocamento dos visitantes dos parques urbanos em Curitiba-PR. Floresta e Ambiente, v. $8, n$. 1 p. 76-83, 2001. DOI: http://www.if.ufrrj.br/revista/pdf/Vol8 76A83.pdf.

HOWARD, Ebenezer. Tomorrow: a Peaceful Path to Real Reform (1898). Garden Cities of Tomorrow, 1946. 
IBGE. Censo Demográfico 2010. Disponível em: https://www.ibge.gov.br/estatisticas/ sociais/educacao/9662-censo-demografico-2010.html?t=sobre. Acesso em: 3 jun. 2020

JAMES, Philip; TZOULAS, Konstantinos; ADAMS, Mags D.; et al. Towards an integrated understanding of green space in the European built environment. Urban Forestry and Urban Greening, v. 8, n. 2, p. 65-75, 2009. DOI: https://doi.org/10.1016/j. ufug.2009.02.001.

JIM, C. Y.; CHEN, Wendy Y. Assessing the ecosystem service of air pollutant removal by urban trees in Guangzhou (China). Journal of Environmental Management, v. 88, n. 4, p. 665-676, 2008. DOI: https://linkinghub.elsevier.com/retrieve/pii/ S0301479707001351

$\mathrm{KABISCH}$, Nadja; HAASE, Dagmar. Green justice or just green? Provision of urban green spaces in Berlin, Germany, Landscape and Urban Planning, v. 122, p. 129-139, 2014. DOI: http://dx.doi.org/10.1016/j.landurbplan.2013.11.016.

KIM, Minseo; RUPPRECHT, Christoph; FURUYA, Katsunori. Residents' Perception of Informal Green Space-A Case Study of Ichikawa City, Japan. Land, v. 7, n. 3, p. 102, 2018. DOI: http://www.mdpi.com/2073-445X/7/3/102

KONIJNENDIJK, Cecil C; ANNERSTEDT, M.; NIELSEN, A. B.; et al. Benefits of Urban Parks - A systematic review. Copenhagen \& Alnarp: [s.n.], 2013. DOI: https://doi. org/10.1016/j.ufug.2009.02.001.

KORAMAZ, Elif Kısar; TÜRKOĞLU, Handan. Measuring and Understanding Urban Parks' Contribution to Quality of Life in Istanbul. Social Indicators Research, v. 138 n. 1 p. $335-351$, 2018. DOI: http://link.springer.com/10.1007/s11205-017-1657-6.

KOTHENCZ, Gyula; BLASCHKE, Thomas. Urban parks: Visitors' perceptions versus spatial indicators. Land Use Policy, v. 64, p. 233-244, 2017. DOI: http://dx.doi. org/10.1016/j.landusepol.2017.02.012.

LACHOWYCZ, Kate; JONES, Andy P. Towards A Better Understanding Of The Relationship Between Greenspace And Health: Development Of A Theoretical Framework. Landscape and Urban Planning, v. 118, p. 62-69, 2013. DOI: http://dx. doi.org/10.1016/j.landurbplan.2012.10.012.

LUZ, France. O Fenômeno Urbano numa região Pioneira: Maringá. Maringá: Prefeitura municipal. 1980.

MARINGÁ, Prefeitura Municipal. Revisão do Plano de Manejo: Parque do Ingá. Maringá: [s.n.], 2007.

MASSAM, Bryan H. Quality of life: Public planning and private living. Progress in Planning, v. 58, n. 3, p. 141-227, 2002.

MELAZO, Guilherme Coelho. Percepção ambiental e educação ambiental: uma reflexão sobre as relações interpessoais e ambientais no espaço urbano. Olhares Trilhas, v. 6 , n. 6 , p. 45-51, 2005. DOI: https://doi.org/10.14393/OT

MENEGUETTI, Karin Schwabe. De cidade-jardim a cidade sustentável : Potencialidades para uma estrutura ecológica urbana em Maringá - PR. Tese (doutorado em Paisagem e Ambiente). Faculdade de Arquitetura e Urbanismo, Universidade de São Paulo, 2007
MENEGUETTI, Karin Schwabe; REGO, Renato Leão; BELOTO, Gislaine Elizete. Maringá - A Paisagem Urbana e o Sistema de Espaços Livres. Paisagem e Ambiente, n. 26 p. 29, 2009. Disponível em: http://www.revistas.usp.br/paam/article/view/77344.

MINAYO, Maria Cecilia De S; SANCHES, Odécio. Quantitativo-qualitativo: oposição ou complementaridade? Cadernos de Saúde Pública, v. 9, n. 3, p. 237-248, 1993. DOI: https://doi.org/10.1590/S0102-311X1993000300002.

MOSTAGI, Nicole Cerci; MANSANO, Sonia Regina Vargas. Planejamento urbano e território vivido: construindo um ideal de cidade verde. IV Congresso Brasileiro de Estudos Organizacionais, 2016.

MUÑOZ, Angelica Maria Mosquera; FREITAS, Simone Rodrigues de. Importância dos Serviços Ecossistêmicos nas Cidades: Revisão das Publicações de 2003 a 2015. Revista de Gestão Ambiental e Sustentabilidade, v. 6, n. 2 p. 89-104, 2017. Disponivel em: http://www.revistageas.org.br/ojs/index.php/geas/article/view/853.

NICHOLLS, Sarah; SHAFER, C Scott. Measuring Accessibility and Equity in a Local Park System : The Utility of Geospatial Technologies to Park and Recreation Professionals. Journal of Park and Recreation Administration, v. 19, n. 4, p. 102-124, 2001.

NIGRO, Giuliano Torrieri; ANGELIS, Bruno Luiz Domingos de. Avaliação da qualidade paisagística para o uso turístico do Parque do Ingá, Maringá (PR). REVSBAU, v. 11, n. 3 , p. $17-36,2016$

ONU. World population prospects: Highlights. New York: Department of Economic and Social Affairs Population Division, 2019. Disponível em: http://www.ncbi.nlm.nih gov/pubmed/12283219.

OPPLIGER, Emilia Alibio; FONTOURA, Fernanda Mussi; OLIVEIRA, Ademir Kleber Morbeck de; et al. A estrutura de áreas verdes urbanas como indicador de qualidade ambiental e sua importância para a diversidade de aves na cidade de Campo Grande Mato Grosso do Sul. Paisagem e Ambiente, v. 30, n. 44, p. 162864, 2019. DOl:

10.11606/issn.2359-5361.paam.2019.162864

PAYNE, Laura L; MOWEN, Andrew J; ORSEGA-SMITH, Elizabeth. An Examination of Park Preferences and Behaviors Among Urban Residents: The Role of Residential Location, Race, and Age. Leisure Sciences, v. 24, n. 2, p. 181-198, 2002. DOl: https:// www.tandfonline.com/doi/full/10.1080/01490400252900149.

RAIMUNDO, Sidnei; SARTI, Antonio Carlos. Parques urbanos e seu papel no ambiente, no turismo e no lazer da cidade. Revista Iberoamericana de Turismo, v. 6 p. $3-24,2016$

RIECHERS, Maraja; BARKMANN, Jan; TSCHARNTKE, Teja. Perceptions of cultura ecosystem services from urban green. Ecosystem Services, v. 17, p. 33-39, 2016. DOI: http://dx.doi.org/10.1016/j.ecoser.2015.11.007.

SANDIFER, Paul A; SUTTON-GRIER, Ariana E.; WARD, Bethney P. Exploring connec tions among nature, biodiversity, ecosystem services, and human health and well-being: Opportunities to enhance health and biodiversity conservation. Ecosystem Services, v. 12, p. 1-15, 2015. DOI: http://dx.doi.org/10.1016/j.ecoser.2014.12.007. 
SANG, Åsa Ode; KNEZ, Igor; GUNNARSSON, Bengt; et al. The effects of naturalness, gender, and age on how urban green space is perceived and used. Urban Forestry \& Urban Greening, v. 18, p. 268-276, 2016. DOI: http://dx.doi.org/10.1016/j. ufug.2016.06.008.

SCHIPPERIJN, Jasper; EKHOLM, Ola; STIGSDOTTER, Ulrika K; et al. Factors influencing the use of green space: Results from a Danish national representative survey Landscape and Urban Planning, v. 95, n. 3, p. 130-137, 2010. DOI: https://doi. org/10.1016/j.landurbplan.2009.12.010

SILVA, Carlos Fabrício Rocha; VARGAS, Maria Augusta Mundim. Sustentabilidade Urbana : Raízes, Conceitos e Representações. v. 6, p. 1-6, 2010.

SOUSA, Paulo Roberto de; HAYASHI, Carmino. PARQUES E RESERVAS FLORESTAIS DO MUNICÍPIO DE MARINGÁ/PR. Periódico Eletrônico Fórum Ambiental da Alta Paulista v. 9 , n. 3, p. $69-84,2013$. DOI: http://amigosdanatureza.org.br/publicacoes/index.php/ forum ambiental/article/view/585.

STECKLER, Allan; MCLEROY, Kenneth R; GOODMAN, Robert M; et al. Toward Integrating Qualitative and Quantitative Methods: An Introduction. Health Education \& Behavior, v. 19, n. 1, p. 1-8, 1992. DOI: https://doi.org/10.1177/10901981920190010

SZEREMETA, Bani; ZANNIN, Paulo Henrique Trombetta. A importancia dos parques urbanos e areas verdes na promocão da qualidade de vida em cidades. RA'EGA Espaço Geográfico em Análise, v. 29, n. 1, p. 177-193, 2013. DOI: http://dx.doi. org/10.5380/raega.v29i0.30747

TAKAHASHI, Leide Yassuco; MARTINS, Sueli Sato. O perfil dos visitantes de um Parque Municipal situado no perímetro urbano. Encontro Nacional Sobre Arborização Urbana, v. 3, p. 197-210, 1990.

TOMIAZZI, André Bellis; VILLARINHO, Fernanda Monteiro; MACEDO, Renato Luiz Grisi; et al. Perfil dos visitantes do parque natural municipal do mendanha município do Rio de Janeiro-RJ. Cerne, v. 12, n. 4, p. 406-411, 2006. DOI: https://www.redalyc. org/articulo.oa?id=74412412.

TYRVÄINEN, Liisa; MÄKINEN, Kirsi; SCHIPPERIJN, Jasper. Tools for mapping social values of urban woodlands and other green areas. Landscape and Urban Planning, v. 79 , n. 1, p. 5-19, 2007. DOI: https://doi.org/10.1016/j.landurbplan.2006.03.003.

TZOULAS, Konstantinos; KORPELA, Kalevi; VENN, Stephen; et al. Promoting ecosystem and human health in urban areas using Green Infrastructure: A literature review. Landscape and Urban Planning, v. 81, n. 3, p. 167-178, 2007. DOI: https://doi. org/10.1016/j.landurbplan.2007.02.001

VAN DEN BERG, Agnes E.; JORGENSEN, Anna; WILSON, Edward R. Evaluating restoration in urban green spaces: Does setting type make a difference? Landscape and Urban Planning, v. 127, p. 173-181, 2014. DOI: http://dx.doi.org/10.1016/j. landurbplan.2014.04.012.

VITOUSEK, Peter M; MOONEY, Harold A; LUBCHENCO, Jane; et al. Human Domination of Earth's Ecosystems. Science, v. 277, n. 5325, p. 494-499, 1997. DOI: 10.1126 science.277.5325.494.

\section{ACKNOWLEDGMENTS}

This study was supported by the CNPq and CAPES. The authors SAS and FRO are grateful for the Master's and/or PhD scholarship granted by the Coordenação de Aperfeiçoamento de Pessoal de Nível Superior (CAPES). They also thank the Conselho Nacional de Desenvolvimento Científico e Tecnológico (CNPq) for the research grants for LFMV and to the Instituto Cesumar de Ciência, Tecnologia e Inovação (ICETI) for supporting LFMV. 


\section{FIELD RESEARCH ON SOCIETY'S PERCEPTION IN RELATION TO THE SOCIO-ENVIRONMENTAL IMPORTANCE OF URBAN PARKS}

This field research aims to understand the perception of the Maringá's population in relation to the environmental and cultural aspects of urban parks.

PARK:

\section{I - USER PROFILE}

1-Gender: A - ( ) Male

B - ( ) Female

2- Age: years old.

3- Scholarity:

4- Neighborhood where you live:

5- Family income:

6- For what purpose do you use the Park??

A - ( ) To practice physical activities

B - ( ) To relax

C - ( ) To contemplate nature

D - ( ) To breathe fresh air

E - ( ) To play with children

F - ( ) For combined activities (two or more activities)

7- How often do you come to the Park?
A - ( ) Everyday
B - ( ) Once a week
C - ( ) On the weekends
D - ( ) Rarely
E - ( ) Others. Which one?

8- How much time do you spend in the park?
A - ( ) Less than 1 hour
B - ( ) 1 hour
C - ( ) 2 hours
D - ( ) 3 hours

E - ( ) More than 3 hours 


\section{9- How do you rate access to the Park?}
A - ( ) Very easy
B - ( ) Easy
$C$ - ( ) More or less
D - ( ) Difficult
E - ( ) Very difficult

10- How do you get to the Park?
A - ( ) On foot
B - ( ) Bicycle
C - ( ) With own vehicle
D - ( ) Public transportation

11- What limits you to frequent the park more?
A - ( ) Lack of time
B - ( ) Insecurity
C - ( ) Physical tiredness
D - ( ) Distance

E - ( ) Others

\section{II - ENVIRONMENTAL PERCEPTION}

12- What is your opinion about the value of nature that makes up this park?
A - ( ) Feeling of peace
B - ( ) Feeling of fear
$\mathrm{C}$ - ( ) Feeling of comfort
D - ( ) Feeling of well-being
E - ( ) Do not know

13- What benefits does the Park provide for the citizen?
A - ( ) Physical and mental health
B - ( ) Thermal comfort
C - ( ) Recreation
D - ( ) Contact with nature
E - ( ) Others. Which one?

14- For you, what kind of benefit does the park provide the city?
A - ( ) Security
B - ( ) Health
C - ( ) Controls the temperature of the city
D - ( ) Pluvial flow
E - ( ) Improves air quality
F - ( ) None of the previous answers
G - ( ) All previous answers
$\mathrm{H}$ - ( ) Other. Which one? 
15- Is green in your life restricted to coming to the Park?

A - ( ) No, I grow plants in my apartment.

B - ( ) No, I have a garden at home.

C - ( ) No, I go to the countryside looking for green.

D - ( ) Yes, I only come to the Park.

\section{III - PARK STRUCTURE}

16- How do you assess the quality of the Park's services?
A - ( ) Bad
B - ( ) Reasonable
C - ( ) Good
D - ( ) Very good

E - ( ) I do not know how to answer

17- What do you use in the park structure?
A - ( ) Bathroom
B - ( ) Trash can
C - ( ) Drinking fountain/water points
D - ( ) Food services
E - ( ) Physical exercise equipment
F - ( ) Others

18- What are the main problems found in the Park?
A - ( ) Lack of maintenance
B - ( ) Garbage
C - ( ) Lack of internal security
D - ( ) Odors
E - ( ) Wild animals and insects
F - ( ) Others

19- Is the Park patrolled regularly by the police?
A - ( ) Always
B - ( ) Often
C - ( ) Sometimes
D - ( ) Almost never
E - ( ) Never 
Silvio Alexandre Santos

Centro Universitário Cesumar - Unicesumar. Programa de PósGraduação em Tecnologias Limpas.

Av. Guedner 1610, Maringá,PR. CEP 87050-900, Brasil

https://orcid.org/0000-0002-6747-6922

silviogeosas@gmail.com

Felipe Rafael Oliveira

Universidade Estadual de Maringá. Programa de Pós-Graduação

em Ecologia de Ambientes Aquáticos Continentais (PEA). Núcleo de Pesquisas em Limnologia, Ictiologia e Aquicultura (NUPÉLIA),

Av. Colombo 5790 - Bloco G90, Maringá, PR. CEP 87020-900, Brasil.

https://orcid.org/0000-0002-7787-1440

felipebio12@outlook.com

Ana Paula Machado Velho

Universidade Estadual de Maringá. Programa de Mestrado Profissional em Agroecologia.

Av. Colombo 5790, Maringá, PR - CEP 87020-900, Brasil

https://orcid.org/0000-0001-9423-6716

anapaula.mac@gmail.com

\section{Luiz Felipe Machado Velho}

Universidade Estadual de Maringá. Programa de Pós-Graduação

em Ecologia de Ambientes Aquários Continentais (PEA). Núcleo de

Pesquisas em Limnologia, Ictiologia e Aquicultura (NUPELIA)

Av. Colombo 5790 - Bloco G90, Maringá, PR. CEP 87020-900, Brasil.

Centro Universitário Cesumar. Programa de Pós-graduação em

Tecnologias Limpas - Sustentabilidade Ambiental. Instituto Cesumar de

Ciência, Tecnologia e Inovação (ICETI).

Av. Guedner 1610, Maringá,PR. CEP 87050-900, Brasil

https://orcid.org/0000-0001-8111-4955

felipe.velho@gmail.com

Nota do Editor

Submetido em: 31/07/2020

Aprovação: 16/02/2021

Revisão: RMO 